\title{
Interstitial mineral assemblages in sheared garnet peridotites from Udachnaya-East kimberlite pipe, Siberian craton
}

\author{
Igor S. Sharygin ${ }^{1}$, Alexander V. Golovin ${ }^{1}$ \\ ${ }^{1}$ Sobolev Institute of Geology and Mineralogy, Siberian Branch of Russian Academy of Science, \\ Koptyuga ave.3, Novosibirsk 630090,Russian Federation, isharygin@igm.ncs.ru,avg@igm.nsc.ru
}

\section{Introduction}

Fragments of mantle rocks, mantle xenoliths, brought to the surface by kimberlite magma are a unique source of information on the composition, origin and evolution of the cratonic lithospheric mantle (CLM). Geochemical studies of peridotite xenoliths indicate that CLM has undergone a complex history of melt extraction that has resulted in depletion of CLM in fusible major elements such as $\mathrm{Fe}, \mathrm{Al}$ and Ca known as basaltic components (Schmidberger and Francis, 2001; Gregoire et al., 2003; Agashev et al., 2013). In contrast to their depletion in magmaphile major elements, peridotite xenoliths are variably enriched in incompatible trace elements. These enrichments are generally believed to be caused by metasomatism, i.e. infiltration of melt or fluid into peridotites, which might be multiple (Schmidberger and Francis, 2001; Gregoire et al., 2003; Agashev et al., 2013). In some cases, metasomatism is accompanied by the growth of new minerals. It is important to establish the chemical nature of metasomatic agent and whether metasomatism is an ancient feature or associated with the kimberlite magmatic event itself.

In this study, we focus on the interstitial mineral assemblages in the sheared peridotites from the uniquely fresh kimberlites of the Udachnaya-East pipe (Siberian craton) and their influence on the xenolith whole-rock geochemistry. For the purpose of our study we choose large xenoliths and investigate their central part, which are free from obvious contamination by host kimberlite.

\section{Results}

The studied xenoliths of the sheared peridotites $(n=25)$ from the Udachnaya-East pipe have rounded, ellipsoidal shapes and are large, $10-25 \mathrm{~cm}$ in size. The sheared peridotites show porphyroclastic to fluidal-mosaic-porphyroclastic textures. The rock-forming (primary) mineral assemblages of the sheared peridotites are olivine $\left(\mathrm{Fo}_{86-91}\right)+$ orthopyroxene + garnet \pm clinopyroxene. The porphyroclasts and neoblasts of both olivine and pyroxene have identical composition for a certain sample. The primary mineral assemblages of the sheared peridotites were equilibrated in the mantle at $1150-1400{ }^{\circ} \mathrm{C}$ and 6.0 7.5 GPa, corresponding to depths of $180-230 \mathrm{~km}$. Primary mineral assemblages of the sheared peridotites also include blebs of $\mathrm{Fe}-\mathrm{Ni}-\mathrm{Cu}$ sulphides enclosed in rock-forming minerals and in intergranular regions.
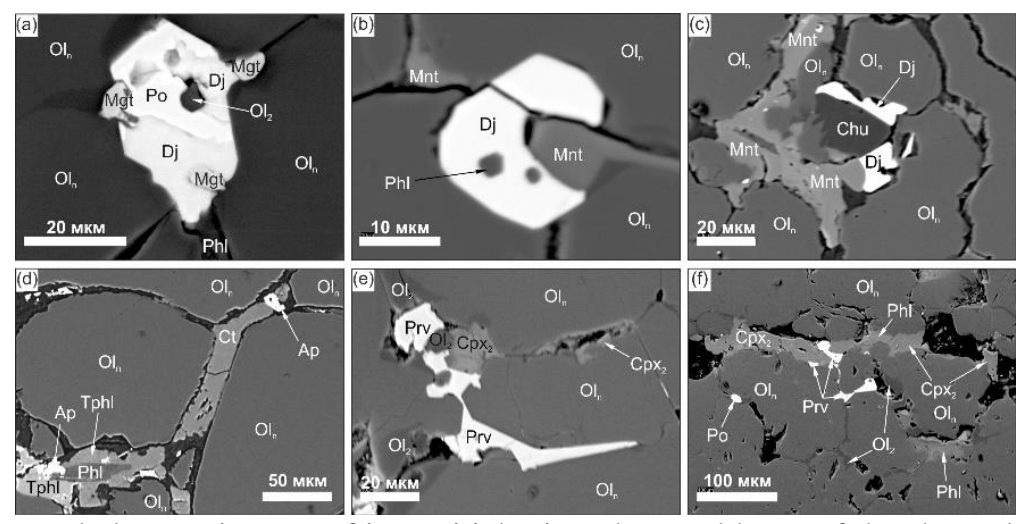

Figure 1: Back-scattered electron images of interstitial mineral assemblages of the sheared peridotites from the Udachnaya-East kimberlite pipe. $\mathrm{Ol}_{n}$ - neoblasts of rock-forming olivine. Interstitial minerals: $\mathrm{Ol}_{2}-\mathrm{olivine} \mathrm{Cpx}_{2}$ - clinopyroxene, Mnt - monticellite, Phl - phlogopite, Thpl - tetraferriphlogopite, Chu - humite, $\mathrm{Ct}$ - calcite, Mgt - magnetite, Prv - perovskite, Ap - apatite, Po - pyrrhotite, Dj - djerfisherite. 
In the sheared peridotites, we have found interstitial mineral assemblages, which include olivine (Fo9394), clinopyroxene, monticellite, mica, humite, clinohumite, sodalite, zoned spinel, perovskite, apatite, calcite, pentlandite, pyrrhotite and djerfisherite $\mathrm{K}_{6}(\mathrm{Fe}, \mathrm{Ni}, \mathrm{Cu})_{25} \mathrm{~S}_{26} \mathrm{Cl}$ (Fig. 1). These late interstitial minerals are mostly localized in triple-junctions between both porphyroclasts and neoblasts of rockforming minerals; less frequently they occur along grain boundaries. Djerfisherite was also observed as rims around blebs of primary $\mathrm{Fe}-\mathrm{Ni}-\mathrm{Cu}$ sulphides. Interstitial olivine and clinopyroxene notably differ in composition from primary ones. Spinel is usually zoned; the core is chromite and the rim is magnetite. Interstitial mica is represented by phlogopite and tetraferriphlogopite.

\section{Discussion}

The interpretation of deformation features suggests that porphyroclastic texture of sheared peridotites results from the recrystallization of granular peridotites under a very high-stress and high strain-rate deformation; the preservation of deformation features implies that recrystallization was essentially contemporaneous with the entrainment of xenoliths by kimberlite magma (O'Reilly and Griffin, 2010). The presence of the studied interstitial minerals between both porphyroclasts and neoblasts of rockforming minerals indicates their close connection with kimberlite magmatism. Mineralogy of the interstitial assemblages, except some minerals, resembles the groundmass of host kimberlites (Sharygin et al., 2007; Kamenetsky et al., 2012). Moreover, composition of some minerals from the interstitial assemblages are similar to those of the kimberlite groundmass of the Udachnaya-East pipe. These facts suggest that the origin of the studied interstitial mineral assemblages in the sheared peridotite is the result of infiltration of transporting kimberlite melt into xenoliths during magma ascent. The majority of interstitial minerals crystallized directly from interstitial kimberlite melt, but djerfisherite rimming primary $\mathrm{Fe}-\mathrm{Ni}-\mathrm{Cu}$ sulphides is the product of their reaction with kimberlite melt.
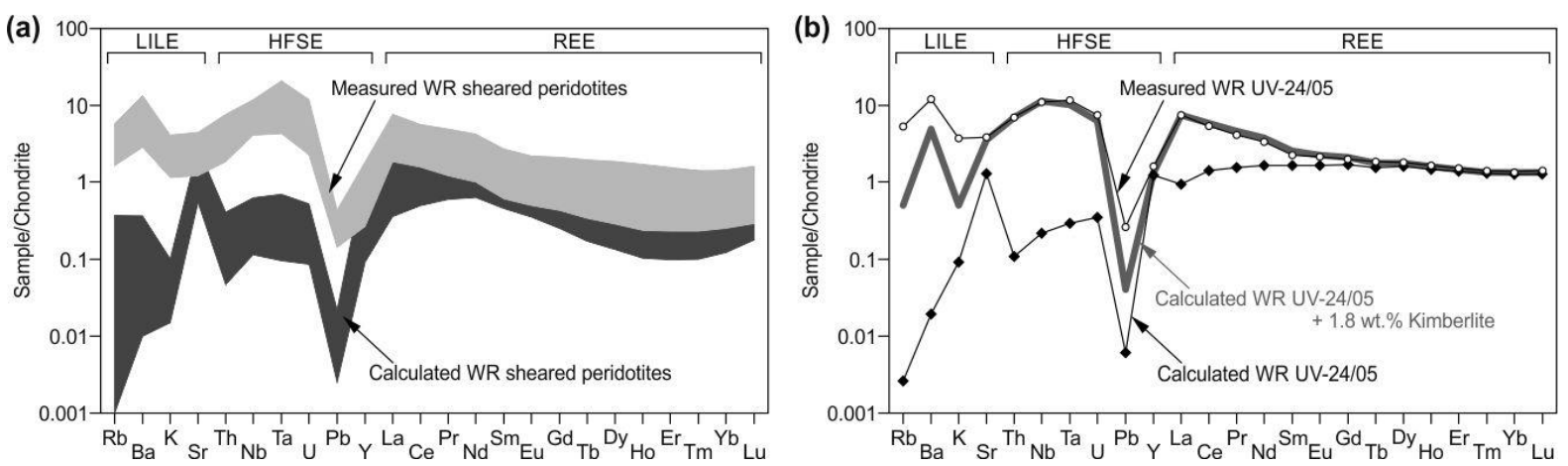

Figure 2: (a) Comparison between chondrite-normalized trace element patterns of measured and calculated whole-rock compositions of the sheared peridotites from the Udachnaya-East kimberlite pipe. (b) Illustration of the effect of transporting kimberlite melt contamination of whole-rock geochemistry of sheared peridotites. Chondrite-normalized trace element patterns of calculated, calculated with the addition of 1.8 wt $\%$ of host kimberlite (Kamenetsky et al., 2012) and measured whole-rock compositions for sample UV-24/05. LILE - large ion lithophile elements, HFSE - high field strength elements, REE - rare earth elements. Chondrite values after McDonough and Sun (1995).

Among rock-forming minerals of peridotites, clinopyroxene and garnet have high amounts of trace elements whereas olivine and orthopyroxene are very poor in trace elements and their contribution to the whole-rock trace elements budget is negligible (Schmidberger and Francis, 2001; Agashev et al., 2013). Therefore, whole-rock trace elements composition of peridotites can be calculated using modal abundances and trace elements contents of clinopyroxene and garnet. The results of such calculations for studied samples indicate that calculated whole-rock trace elements contents are much lower than those measured (Fig. 2). In particular, calculated whole-rock LILE and HFSE abundances are an order(s) of magnitudes lower than those analysed (Fig. 2). Previous studies of mantle xenoliths in kimberlites from other regions demonstrated the same problem (Schmidberger and Francis, 2001; Gregoire et al., 2003). Such large discrepancy for trace elements between the calculated and measured whole-rock compositions can be explained by the presence of tiny accessory phases that contribute significantly to the whole-rock trace elements budget of peridotites. 
We identified at least 16 interstitial minerals, which are related to infiltration of transporting kimberlite melt. Among them, perovskite and apatite are the main storage of REE, $\mathrm{Nb}$ and $\mathrm{Ta}$, calcite $-\mathrm{Sr}$, djerfisherite $-\mathrm{K}$, mica $-\mathrm{K}, \mathrm{Rb}$ and $\mathrm{Ba}$. We modeled infiltration of kimberlite melt into the xenoliths of the sheared peridotites by the addition of up to $2 \mathrm{wt} \%$ of host kimberlite to the calculated whole-rock compositions. The results yielded trace elements patterns that are remarkably similar to those of the analysed bulk rocks (Fig. 2b). This coincidence supports the conclusion that interstitial mineral assemblages in the sheared peridotite is the result of infiltration of transporting kimberlite melt into xenoliths.

\section{Conclusions}

The xenoliths of the sheared peridotites from the Udachnaya-East kimberlite pipe contain interstitial mineral assemblages, which include olivine, clinopyroxene, monticellite, mica, humite, clinohumite, sodalite, zoned spinel, perovskite, apatite, calcite, pentlandite, pyrrhotite and djerfisherite. These minerals crystallized from interstitial kimberlite melt that infiltrated into xenoliths during magma ascent.

The presence of kimberlite-related interstitial minerals (such as perovskite, apatite, carbonate, mica, and djerfisherite) may have an essential influence on the whole-rock trace elements composition of mantle xenoliths. The sheared peridotites had depleted trace elements patterns before contamination by transporting kimberlite melt. This fact should be considered when we use measured bulk geochemical characteristics of mantle xenoliths (even only the central parts of the large xenoliths) for the interpretation of the ancient mantle processes in CLM.

\section{Acknowledgements}

This work was supported by the grant No. 16-35-60052 mol_a_dk from the Russian Foundation for Basic Research, the grant No. MK-4534.2016.5 from the President of the Russian Federation and the state assignment project No. 0330-2016-0006.

\section{References}

Agashev AM, Ionov DA, Pokhilenko NP, Golovin AV, Cherepanova Y, Sharygin IS (2013) Metasomatism in lithospheric mantle roots: Constraints from whole-rock and mineral chemical composition of deformed peridotite xenoliths from kimberlite pipe Udachnaya. Lithos 160-161:201215

Gregoire M, Bell DR, Le Roex AP (2003) Garnet lherzolites from the Kaapvaal craton (South Africa): Trace element evidence for a metasomatic history. J Petrol 44:629-657

Kamenetsky VS, Kamenetsky MB, Golovin AV, Sharygin VV, Maas R (2012) Ultrafresh salty kimberlite of the Udachnaya-East pipe (Yakutia, Russia): A petrological oddity or fortuitous discovery? Lithos 152:173-186

McDonough WF, Sun SS (1995) The composition of the Earth. Chem Geol 120:223-253

O'Reilly SY, Griffin WL (2010) The continental lithosphere-asthenosphere boundary: Can we sample it? Lithos 120:1-13

Schmidberger SS, Francis D (2001) Constraints on the trace element composition of the Archean mantle root beneath Somerset Island, Arctic Canada. J Petrol 42:1095-1117

Sharygin IS, Golovin AV, Pokhilenko NP (2012) Djerfisherite in xenoliths of sheared peridotite in the Udachnaya-East pipe (Yakutia): origin and relationship with kimberlitic magmatism. Russian Geology and Geophysics 53:247-261 